\title{
Unusual cause of neck pain
}

\author{
Pakhi Goel, ${ }^{1}$ Naveen Premnath, ${ }^{2}$ Mugdha Agrawal, ${ }^{3}$ Arjun Gupta ${ }^{1}$
}

${ }^{1}$ Internal Medicine, University of Texas Southwestern Medical Center, Dallas, Texas, USA ${ }^{2}$ Internal Medicine, Icahn School of Medicine at Mount Sinai St Luke's-Roosevelt Hospital Center, New York, New York, USA

${ }^{3}$ Rheumatology, University of Pennsylvania Perelman School of Medicine, Philadelphia, Pennsylvania, USA

\section{Correspondence to}

Arjun Gupta,

guptaarjun90@gmail.com

Accepted 14 February 2018

\section{DESCRIPTION}

A 69-year-old man with hyperlipidaemia presented to the emergency department with a 4-day history of new onset pain in the neck. The pain was severe (rated 9/10 in severity), constant, localised to the base of the skull and was associated with significant restriction of neck motion; any movements resulted in dramatic worsening of the pain. $\mathrm{He}$ also reported subjective fevers at home. He did not report trauma, photophobia, phonophobia, nausea, vomiting, insect bites, visual disturbances, trouble swallowing or speaking, jaw claudication or morning stiffness. There were no sick contacts. He did not have pain at any other sites. He had tried some topical diclofenac gel for the past 2 days without much relief. His only scheduled medication was atorvastatin.

On physical examination, his temperature was $38.1^{\circ} \mathrm{C}$, blood pressure was $128 / 82 \mathrm{~mm} \mathrm{Hg}$, heart rate was $82 / \mathrm{min}$ and respiratory rate was $14 / \mathrm{min}$. He was visibly trying not to move his neck, and the range of passive motion in the neck was restricted. Systemic examination including detailed neurological and musculoskeletal examinations were within normal limits; there was no papilloedema.

The differential diagnoses were broad at this time, including musculoskeletal causes, meningitis and giant cell arteritis. Laboratory analysis revealed a neutrophilic leucocytosis (white cell count $15.3 \times 10^{9} / \mathrm{L}, 92 \%$ neutrophils) and elevated inflammatory markers (erythrocyte sedimentation rate $40 \mathrm{~mm} / \mathrm{h}$, C-reactive protein $12 \mathrm{mg} / \mathrm{dL}$ ). Blood cultures were drawn (later reported no

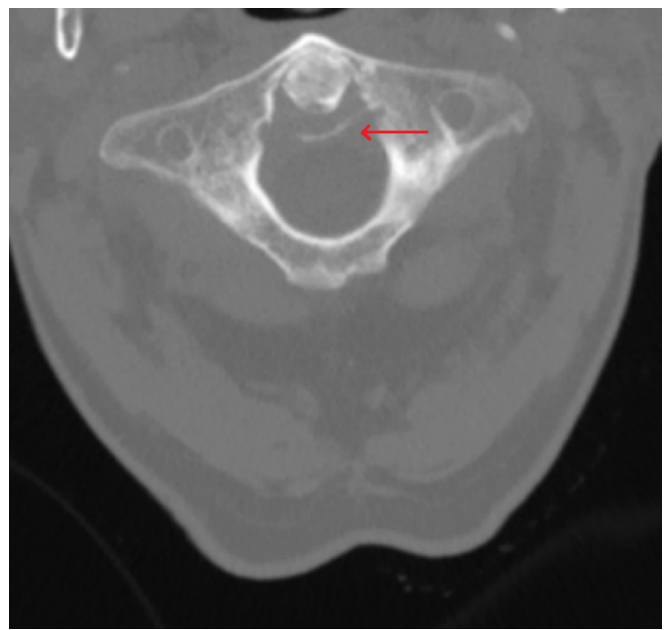

To cite: Goel $P_{\text {, Premnath }} \mathrm{N}_{\text {, }}$ Agrawal $\mathrm{M}$, et al. BMJ Case Rep Published Online First: [please include Day Month Year]. doi:10.1136/bcr-2018224183
Figure 1 Axial view of a non-contrast CT scan of the cervical spine performed on a patient presenting with excruciating neck pain with any movement. Note the granular calcification posterior to the odontoid process (red arrow), consistent with the crowned dens syndrome. growth) and a lumbar puncture was performed which was unremarkable. A plain radiograph of the neck revealed mild degenerative joint changes. A non-contrast CT scan of the cervical spine showed calcification posterior to the odontoid process (figure 1). A diagnosis of crowned dens syndrome was made, and scheduled ibuprofen therapy was initiated and the patient discharged. At a follow-up 1 week later, the patient reported near-complete relief of symptoms, and ibuprofen was discontinued.

Crowned dens syndrome is a rare, inflammatory manifestation of calcium pyrophosphate crystal deposition disease, first described in $1985 .{ }^{1}$ It occurs most commonly in the elderly (age $>70$ years). ${ }^{2}$ It usually presents with acute or recurrent, severe, axial neck pain. Pain is usually localised to the base of the skull, with restricted neck motion (especially rotation). ${ }^{2}$ Fevers and elevated inflammatory markers are typical. Chondrocalcinosis, or deposition of hydoxyapatite crystals in any of the periodontal ligaments surrounding the odontoid process (also called the 'dens') of the axis (second cervical vertebra) gives the appearance of a 'crown' surrounding it. This is usually evident on CT scans of the cervical spine. ${ }^{3}$ Plain radiographs may not demonstrate this finding.

The acute presentation and combination of neck pain, fever and elevated inflammatory markers can be alarming for the presence of polymyalgia rheumatica, giant cell arteritis, meningitis or inflammatory spondylarthrosis such as rheumatoid arthritis. ${ }^{2}{ }^{3}$ Clinicians must maintain a strong suspicion to be able to diagnose this condition. It generally responds favourably

Learning points

The crowned dens syndrome is a rare, inflammatory manifestation of calcium pyrophosphate crystal deposition disease. Hydroxyapatite crystal deposition in the ligaments surrounding the odontoid process of the second cervical vertebra (the 'dens') can give rise to the appearance of a 'crown' around it on computed tomographic scans, giving rise to the name 'crowned dens syndrome'.

- It usually affects the elderly, who present with acute neck pain/stiffness accompanied by fever and elevated inflammatory markers. Symptoms may resemble those of polymyalgia rheumatica, giant cell arteritis, meningitis or inflammatory spondylarthrosis such as rheumatoid arthritis.

- Treatment with non-steroidal anti-inflammatory drugs or colchicine is generally successful. 
to short courses of non-steroidal anti-inflammatory drugs or colchicine. ${ }^{2}{ }^{3}$ Complications are rare, but cervical cord compression can occur due to developing inflammatory pannus.

Contributors All authors participated sufficiently in the work to take public responsibility for the content, including participation in the concept, design, analysis, writing or revision of the manuscript.

Funding This research received no specific grant from any funding agency in the public, commercial or not-for-profit sectors.

Competing interests None declared.

Patient consent Obtained.
Provenance and peer review Not commissioned; externally peer reviewed.

(C) BMJ Publishing Group Ltd (unless otherwise stated in the text of the article) 2018. All rights reserved. No commercial use is permitted unless otherwise expressly granted.

\section{REFERENCES}

1 Bouvet J-P, Parc J-ML, Michalski B, et al. Acute neck pain due to calcifications surrounding the odontoid process: the crowned dens syndrome. Arthritis Rheum 1985:28:1417-20

2 Shikino K, Ota T, lkusaka M. Crowned dens syndrome Am J Med. 2017;130:e111-e112.

3 Aouba A, Vuillemin-Bodaghi V, Mutschler C, et al. Crowned dens syndrome misdiagnosed as polymyalgia rheumatica, giant cell arteritis, meningitis or spondylitis: an analysis of eight cases. Rheumatology 2004;43:1508-12.

Copyright 2018 BMJ Publishing Group. All rights reserved. For permission to reuse any of this content visit

http://group.bmj.com/group/rights-licensing/permissions.

BMJ Case Report Fellows may re-use this article for personal use and teaching without any further permission.

Become a Fellow of BMJ Case Reports today and you can:

- Submit as many cases as you like

- Enjoy fast sympathetic peer review and rapid publication of accepted articles

Access all the published articles

Re-use any of the published material for personal use and teaching without further permission

For information on Institutional Fellowships contact consortiasales@bmjgroup.com

Visit casereports.bmi.com for more articles like this and to become a Fellow 